6. Фіксуючи результати спостереження, звертайте увагу на те, як спостережуване явище відбувається у часі та які умови його протікання.

7. Пам'ятайте, що ціль спостереження - зафіксувати ознаки та особливості спостережуваних процесів і явищ та на основі їхнього аналізу, порівняння, узагальнення виявити певні причинно-наслідкові зв'язки, закономірності та протиріччя.

8. Сформулюйте проблемні запитання, що виникли у результаті аналізу результатів досліду?

Учні виконують експериментальне завдання, спираючись на узагальнений план-орієнтир. Таким чином, вони засвоюють орієнтувальну основу діяльності, елементи методологічних знань високого рівня узагальнення. Такі знання, згідно 3 концепцією нормативної творчої діяльності, $\epsilon$ ефективним засобом творчості учнів [5].

Висновки. Результати проведеного педагогічного дослідження свідчать, що коли завдання, подібні до розглянутих у публікації, виконуються з опорою на вдало підібрані вчителем орієнтири, то вони сприймаються учнями не як репродуктивні, а як творчі. Застосування орієнтирів дозволяє учням побачити «між рядками» змісту, на перший погляд, репродуктивного завдання, приховану в ньому ще одну вимогу, а саме: вийти за межі даного завдання, виявити протиріччя у результатах досліду, сформулювати проблему. Таким чином, діяльність набуває творчого характеру, реалізується один із визначених нами принципів організації творчої навчальної діяльності - принцип домінантного перетворення репродуктивної діяльності у творчу [3]. Особливо це актуально у контексті реалізації проблемного навчання, застосування активних дидактичних методів: евристичного, дослідницького, методу проєктів.

\section{СПИСОК ВИКОРИСТАНОЇ ЛІТЕРАТУРИ}

1. Богоявленская Д. Б. Психология творческих способностей : учеб. пособие для студ. высш. учеб. заведений. Москва : Академия, 2002. 320 с.

2. Галатюк Т. Ю. Модель методологічної культури учня в контексті вивчення природничих предметів. Збірник наукових праць Кам'янещь-Подільського національного університету імені Івана Огієнка. Серія «Педагогічна». Кам'янець-Подільський : Кам'янець-Подільський національний університет імені Івана Огієнка, 2015. Вип. 21. С. 178-181.

3. Галатюк Т., Галатюк Ю. Творча пізнавальна ситуація як чинник у формуванні методологічної культури учня. Нова педагогічна думка : науково-методичний журнал. Рівне, 2019. № 4. С. 142-145.

4. Галатюк Ю. М. Особливості проєктування творчої навчальної діяльності на основі методу спостереження. Наукові записки Рівненського державного гуманітарного університету : збірник наукових праць. Рівне : РДГУ, 2016. Вип. 14 (57). С. 32-35.

5. Калошина И. П. Структура и механизм творческой деятельности. Москва : Изд-во МГУ, 1983. 168 с.

6. Нова українська школа. URL : https://mon.gov.ua/ ua/tag/nova-ukrainska-shkola (дата звернення: 10.11.2020).

7. Новиков А. М. Методология. Москва : СИНТЕГ, 2007. 668 с.

8. Павленко А. I. Методика навчання учнів середньої школи розв'язуванню і складанню фізичних задач (теоретичні основи). Київ : Міжнародна фінансова агенція, 1997. 177 с.

9. Пономарев Я. А. Психология творения. Воронеж : Издательство НТО «МОДЭК», 1999. 480 с.

Дата надходження до редакиї: 12.11.2020 p.
Людмила ЛЕЙБИК,

викладач-методист фізики та астрономії

Луиьького педагогічного коледжу

\title{
ФОРМУВАННЯ ЦІЛСНОСТІ СПРИЙНЯТТЯ СВІТУ В СТУДЕНТІВ ПЕДАГОГІЧНОГО КОЛЕДЖУ У ПРОЦЕСІ ВИВЧЕННЯ ПРЕДМЕТА «ФІЗИКА ТА АСТРОНОМІЯ»
}

У статті зосереджено увагу на інтегруванні фізичних та астрономічних знань, що забезпечує системний виклад матеріалу в нових органічних взаємозв'язках, теоретичне узагальнення, розширене трактування набутих студентами знань.

Ключові слова: інтеграція, фізичний складник, астрономічний складник, ијілісність сприйняття світу.
Modern educational theory and practice prove that creativity, adaptability, critical thinking and cooperation are very valuable skills, because in a dynamic world focused on development, exchange of information and knowledge, professionals who can both combine and apply their knowledge from several disciplines are the ones with the distinct advantage. 
When it comes to students acquiring these skills, integrated learning is an extremely effective approach, as the teacher has the opportunity to demonstrate remarkable creativity, previously limited to the standards of one subject, and students have the opportunity to get a holistic picture of the world and skills required in real life. This article is devoted to the study of combining the course of physics and astronomy on a single integrated humanities basis with the creation of qualitatively new approaches to teaching the course "Physics and Astronomy» in the college, presenting an effective tool for the students to form a holistic picture of the world. Since physics and astronomical components of the educational field «Science» largely share the subject matter, research methods and, as a rule, jointly contribute to the formation of the scientific picture of the world, it is sensible to combine these two components into a single subject «Physics and Astronomy" without losing specifics of each of these components. The article focuses on the integration of physics and astronomical knowledge in studying «Atomic and Nuclear Physics» topic, which provides a systematic presentation of the material with new organic links, theoretical generalization, expanded interpretation of previously acquired knowledge. The development and essence of the integration in education; didactic principles of selection and integration of the physics and astronomical components' content and their implementation in teaching this topic constitute the research subject of this article.

Key words: integration, physics component, astronomical component, integrity of world perception.

Постановка проблеми. У Концепції Нової української школи зазначено, що випускник школи повинен бути особистістю, патріотом та інноватором, який «здатний змінювати навколишній світ, розвивати економіку за принципами сталого розвитку, конкурувати на ринку праці, вчитися впродовж життя» $[5$, с. 6]. Водночас формула Нової української школи містить дев'ять ключових компонентів, серед яких визначальними нині у глобальному розумінні є новий зміст освіти і сучасне освітнє середовище, яке «дає змогу добре засвоїти новий зміст і набути компетентностей для життя» $[5$, с. 7]. Серед десяти ключових компетентностей чільне місце займають математична компетентність, компетентності у природничих науках i технологіях, інформаційно-цифрова грамотність, уміння навчатися впродовж життя та інші [5, с. 11-12], що також покладено до цільових орієнтирів STEM-підходу у навчанні.

Багаторічний досвід роботи та проведені дослідження показують, що астрономічна компонента освітньої галузі «Природознавство» багатьма студентами коледжу засвоюється формально. На це є дві причини: 1) значний об’єм і складність матеріалу, який вивчається; 2) мала кількість навчальних годин. Тому знання студентів часто бувають неповні, до того ж вони не вміють застосовувати їх для розв'язання конкретних навчальних і практичних задач. Це створює проблему підвищення ефективності навчання астрономії та сумісних із нею навчальних дисциплін, зокрема й фізики. Прослідковується також «протиріччя між високим рівнем вимог до сучасної освітньої галузі «Природознавство» (у частині ії фізичної та астрономічної компонент), з одного боку, та недостатнім рівнем методичної підготовки майбутніх учителів фізики й астрономії до проведення пропедевтики астрономічних знань - 3 іншого» [1, с. 3$]$.
Отже, сучасна реформа освіти вимагає вдосконалення викладання природничих дисциплін, зокрема фізики та астрономіі. Одним зі шляхів виходу із ситуації, яка склалася, можна вважати впровадження інтегрованого курсу фізики та астрономії, спрямованого на забезпечення принципу неперервності природничої освіти та підвищення якості формування основних природничо-наукових понять. На завданні часткової або повної інтеграції фізичного й астрономічного компонентів освіти акцентується увага i в державних стандартах базової та повної середньої освіти. Діяльнісний підхід, наголошується в документі, має бути «спрямований на розвиток умінь i навичок учня, застосування здобутих знань у практичних ситуаціях, пошук шляхів інтеграції до соціокультурного та природного середовища» [2].

Оскільки засвоєння фізичного та астрономічного компонентів освітньої галузі «Природознавство» мають споріднений предмет навчання, методи дослідження i, як правило, спільний внесок у формування наукової картини світу, пропонується ці два компоненти об'єднати в єдиний навчальний предмет «Фізика та астрономія», не втрачаючи при цьому своєрідності кожного 3 них. «При цьому слід урахувати, що фізичний складник забезпечує ознайомлення $з$ фундаментальними фізичними теоріями, а зміст астрономічного складника - опанування методів вивчення законів руху, фізичної природи, еволюції небесних тіл та Всесвіту в цілому» [9]. На нашу думку, саме такий підхід є пріоритетним у формуванні ключових компетентностей засобами навчального предмета «Фізика та астрономія», що забезпечує формування цілісності сприйняття світу.

Аналіз наукових досліджень і публікацій. Здійснення реформування системи освіти вимагає від викладача високого професійного рівня підготовки, здатного максимально розвивати інтелектуальний потенціал і формувати світогляд студента. У зв'язку 3 цим варто говорити про «нову роль учителя - не як єдиного наставника та джерело знань, а як коуча, фасилітатора, тьютора, модератора в індивідуальній освітній траєкторії дитини» [5, с. 16]. У цьому контексті саме система інтегрованого навчання, хоча ще й недостатньо розроблена та впроваджена в освітній процес, має низку позитивних відмінностей порівняно з іншими підходами. Науковці все «більше схиляються до широкого використання міжпредметних зв'язків та інтеграції фізики й астрономії в основній та старшій школі» [1, с. 2].

Як відомо, вперше поняття «інтеграція» було використано у XVII столітті Я.-А. Коменським у праці «Велика дидактика», де вчений зауважував: «Усе, що знаходиться у взаємозв'язку, повинно викладатися у такому ж взаємозв'язку». Необхідність інтегрованого підходу до організації навчально-виховного процесу великий педагог пояснював так: «Усі знання виростають $з$ одного коріння - навколишньої дійсності, мають між собою зв'язки, а тому повинні вивчатися у зв'язках» [3]. Його наступник, Й.-Г. Песталоцці, у творі «Лінгард і Гертруда» розглядалав інтеграцію як метод навчання.

Інтеграція, на думку науковців (К. Колєсіна, Ю. Колягін, А. Миронов), можлива за умов, коли поняття, які розглядаються, будуть пов'язуватися 3 методами пізнання. Дитина повинна засвоїти не тільки знання, а й той спосіб мислення, за допомогою якого воно було отримане [8]. 
Е. Носенко подає один із варіантів інтегрування змісту освіти, користуючись поняттям «картина світу» як інтегруючим фактором. Авторка для створення в дітей цілісного образу світу пропонує використовувати такий підхід: «річ - властивість - відносини» [10].

Учені (О. Алексенко, Ю. Колягін, Н. Свєтловська) цілком справедливо зазначають, що інтеграція передбачає наявність знань. Тобто, перш ніж об'єднувати істотні властивості про об'єкт в одне ціле, необхідно спочатку сформувати уявлення про ці властивості. Висловлені думки актуалізують проблему місця і ролі інтеграції як методичного явища, іiї можливостей в освітньому процесі [11].

Український психолог М. Костюк вважав, що «інтеграція - це процес взаємодії елементів із заданими властивостями, що супроводжується встановленням, ускладненням і зміцненням істотних зв'язків між цими елементами на основі достатньої підстави, в результаті якої формується інтегрований об'єкт (цілісна система) з якісно новими властивостями, у структурі якого зберігаються індивідуальні властивості вихідних елементів [6].

Питання інтеграції фізичного й астрономічного складників загальноосвітнього предмета «Фізика та астрономія» у науковій літературі має чимало прихильників та опонентів. Зберегти астрономію як самостійний предмет при одночасному вдосконаленні методики викладання астрономії на III ступені навчання в середній школі пропонують I. Климишин, I. Крячко та М. Пришляк. Питання інтеграції фізики й астрономії для старшої профільної школи досліджував Т. Засєкін та інші вітчизняні вчені [12].

Об'єднати курс фізики та астрономії на єдиній інтегровано-гуманітарній основі зі створенням якісно нового інтегрованого курсу «Фізика. Астрономія» в основній школі пропонує відомий український фізик-методист М. Мартинюк. Він, зокрема, зауважує, що «...близькість і в багатьох випадках спільність предмета та методів фізичної й астрономічної наук та їх взаємодія у сучасному пізнанні природи $є$ основою, на якій може здійснитися інтеграція змісту загальної фізичної й астрономічної освіти» [7].

Мета статі - дослідити проблему пошуку нових підходів до структурування знань 3 фізики та астрономії як засобу цілісного розуміння й пізнання світу студентами Луцького педагогічного коледжу на заняттях $з$ предмета «Фізика та астрономія».

Виклад основного матеріалу. У сучасному динамічному світі, який зосереджується на розвитку, обміні знаннями та інформацією, виграють ті, хто за необхідності вміє одночасно і поєднувати, і застосовувати свої знання 3 декількох дисциплін. Складно уявити сучасний світ без технологій. Вони формують не лише наше майбутнє, а й світ довкола. Тому так важливо, щоб студенти оволоділи навичками критичного мислення, комплексного вирішення проблем, креативності, розуміння технічних процесів i способів застосування науково-технічних знань у реальному житті. Коли йдеться про набуття цих навичок студентами, інтегроване навчання $є$ надзвичайно ефективним підходом, оскільки викладач має можливість проявити неабияку творчість, яка раніше обмежувалася стандартом одного предмета, а студенти відповідно - отримати систему знань, що формує науковий світогляд, а отже, і сучасне мислення, що забезпечує цілісне сприйняття картини світуі формування навичок, необхідних у реальному житті.
Зазначимо, що інтеграція (від лат. - повний, ицілісний) - це створення нового цілого на основі виявлення однотипних елементів і частин із кількох раніше розрізнених одиниць. Із позиції педагогіки, інтеграція - це процес взаємопроникнення наук (навчальних предметів, видів діяльності тощо) [1]. У цьому контексті варто зазначити, що сама специфіка фізики та астрономії на сучасному рівні спонукає до комплексного підходу у вивченні цих предметів, тобто логіка означених наук вимагає їх об'єднання, інтеграції. Таким чином, органічне поєднання відомостей 3 астрономії навколо певної теми фізики $\epsilon$ однією з найперспективніших інновацій, що закладає нові умови діяльності викладачів та студентів під час вивчення предмета «Фізика та астрономія». На наш погляд, саме інтегровані заняття спрямовані на встановлення міжпредметних зв'язків і сприяють формуванню в студентів цілісного, системного світогляду, актуалізації особистісного ставлення до питань, що розглядаються. Отже, слід переорієнтуватися з мети досягнення формальних результатів на дійсне розуміння матеріалу, яке може прийти лише через інтердисциплінарні заняття (STEM-заняття), що дійсно $\epsilon$ ефективними і подобаються студентам.

Як приклад, розглянемо інтегрування фізичних та астрономічних знань при вивченні теми «Атомна та ядерна фізика».

Вивчення даної теми розпочинаємо зі створення мотиваційної ситуації: «3 чого складається Всесвіт?». Застосовуючи «мозковий штурм», пригадуємо, що всі матеріальні об'єкти навколо нас складаються 3 частинок, які ми називаємо молекулами. Молекули відповідно складаються з атомів. Молекули часто розпадаються, утворюючи нові молекули.

Передусім варто замислитися, що майже всі атоми, які сьогодні складають усю живу і неживу природу, існують впродовж мільярдів років та утворилися в місцях, далеких від нашої планети. Як же утворилися ці атоми? Звичайно, все розпочалося майже 14 мільярдів років тому з події, яку ми називаємо Великим вибухом. А результатом такої події стало утворення Всесвіту, що складався виключно із газу (водень, гелій). Зрештою із газової хмари утворилися великі щільні газові кулі, що стискалися під дією власної сили тяжіння, через що нагрівалися всередині. У певний момент ядро такої кулі стало достатньо гарячим, щоб почався термоядерний синтез (який вивчається у розділі фізики «Атомна та ядерна фізика»). Енергія, яка вивільняється в результаті термоядерного синтезу, підтримує силу газового тиску. I коли ця сила стає рівною силі тяжіння, що притягує газ до центру, досягається стан рівноваги. У результаті цього народжується зоря. Протягом іiі життя реакції синтезу в ядрі будуть виробляти не лише гелій, а й вуглець, кисень, азот, а також усі інші елементи періодичної системи аж до заліза. Із часом реакції у ядрі припиняються. Це викликає неймовірно потужний вибух, який ми називаємо «надновою». Цей вибух вивільняє настільки багато енергії, що синтез протікає надзвичайно бурхливо, що формує елементи, атоми яких важчі за залізо (срібло, золото, уран). Усі елементи, які накопичилися в ядрі зірки (вуглець, азот, залізо та ін.) викидаються у міжзоряний простір, де змішуються з газом, який міститься там. Історія повторюється. Газові хмари, які тепер містять чимало елементів, мають області підвищеної щільності, які притягують 
більшу кількість речовини. Як і раніше, результатом цього є утворення нових зірок. Саме таким чином близько п'яти мільярдів років тому утворилося Сонце. Але якщо перші зорі містили виключно водень та гелій, то в Сонця два відсотки маси зорі складають інші елементи періодичної системи.

Далі наголошуємо, що формування планет, зокрема Землі, - це процес, побічний від процесу утворення зір. Планети формуються 3 тієї ж газової хмари, що й зірка. Однак невеликі планети, такі, наприклад, як Земля, не мають достатньої сили тяжіння для утримання помітної кількості водню та гелію, оскільки обидва ці гази дуже легкі. Таким чином, саме важкі елементи є основною частиною маси нашої планети та всього на ній, зокрема й кожного із нас! Отже, за винятком водню та деякої частини гелію, все навколо нас (і ми самі) складається 3 атомів, які утворилися всередині зірок. Хімічний склад Сонця підтверджує основне положення про матеріальну єдність світу.

Виникає запитання "Чи визначає заняття, яке ми створюємо, проблему реального світу?». Так, оскільки ми приходимо до надзвичайно важливого висновку: небесні тіла складаються 3 тих самих елементів, що й Земля. Як бачимо, завдяки інтеграції фізичних та астрономічних знань ознайомлюємо студентів із навколишнім світом від елементарних частинок і атомів до Галактики і Всесвіту в цілому, показуємо взаємозв'язок фізики та астрономії; розкриваємо єдність людини і природи, з'ясовуємо роль і місце фізики та астрономії у збереженні цивілізації та розв'язанні глобальних проблем людства.

Як правило, студенти відразу цікавляться: «A як же визначають хімічний склад, вік Сония та інших зір?». Важливо наголосити, що подібна інформація зазвичай отримується через виявлення та аналіз видимого світла та інших спектрів електромагнітного випромінювання. Астрономічні спостереження розділяють відповідно до ділянок електромагнітного спектра, в яких проводяться вимірювання. Деякі частини спектра можна спостерігати 3 поверхні Землі, а інші спостереження ведуться тільки на великих висотах або в космосі. А оскільки будь-яке випромінювання зумовлене фізичними процесами, що відбуваються у світі атомів, то при вивченні будови атома особливу увагу приділяємо основним законам поглинання і випромінювання енергії як окремими атомами, так i їх сукупністю (у газах, рідинах і твердих тілах).

Розглядаючи будову атома за так званою планетарною моделлю, наголошуємо студентам на тому, що реальний атом значно складніший, ніж його планетарна модель. Одна з основних відмінностей атомної системи полягає в тому, що електрон може рухатися навколо ядра не по будь-яких, а лише по певних орбітах, які називають стаціонарними. Радіуси стаціонарних орбіт $r_{n}$ і швидкість руху $v_{n}$ мають бути такими, щоб момент кількості руху електрона, обчислений відносно ядра, був цілим кратним сталого для всіх атомів елементарного моменту $\frac{h}{2 \pi} n$ :

$$
r_{n} \cdot m_{e} \cdot v_{n}=\frac{h}{2 \pi} n
$$

де $n$ набуває значення чисел натурального ряду 1, 2, 3 і т. д., а величина $h$ - стала Планка.

Чим більший радіус орбіти, тим більша повна енергія (потенціальна і кінетична) електрона, який рухається цією орбітою. Тут доцільною є така аналогія: чим більша відстань від Землі, на яку необхідно запустити штучний супутник, тим більшої початкової швидкості йому треба надати, тобто тим більшу повну енергію він повинен мати у початковий момент, а отже, і має зберегти ії в процесі руху орбітою. 3 іншого боку, якби електрони рухалися навколо ядра подібно до планет навколо Сонця, то кожен атом був би єдиним і неповторним, оскільки згідно з класичною механікою, кожен електрон міг би рухатися вздовж будь-якої з безкінечної кількості орбіт. Відповідно мала б спостерігатися безкінечна різноманітність атомів одного і того ж хімічного елемента. Як відомо, щоб усунути недоліки цієї моделі, данський фізик Нільс Бор, міркуючи над проблемою стійкості планетарного атома, доповнив іiі постулатами, відомими як «постулати Бора».

Наступним важливим меседжем $є$ те, що схожість атомів одного і того ж хімічного елемента пояснюється тим, що стаціонарні орбіти електронів в усіх атомах даного елемента однакові. Без надходження енергії ззовні атоми можуть переходити тільки в стан із меншою енергією. Звичайно, атом перебуває у збудженому стані недовго (близько $10^{-8} \mathrm{c}$ ) після чого переходить в основний стан. Проте кожен окремий хімічний елемент має свою характерну тільки для нього структуру електронних орбіт і схему енергетичних рівнів його атомів. Як наслідок - атоми певного елемента можуть поглинати і випромінювати кванти лише певної, характерної для даного хімічного елемента частоти. При цьому вони можуть випромінювати лише ті кванти, які здатні поглинати, i навпаки. Звідси випливає важливий висновок: за схемою енергетичних рівнів атомів, які входять до складу газової суміші різних хімічних елементів, можна встановити хімічний склад суміші (тобто їі якість). Варто підкреслити, що даний висновок покладений в основу надзвичайно важливого методу якісного спектрального аналізу.

Щоб провести якісний спектральний аналіз, тобто, щоб визначити спектральний склад випромінюючого газу, насамперед необхідно знати, в яких лініях (в яких довжинах хвиль) випромінюють атоми. Порівнюючи виміряні положення відомих ліній у спектрі порівняння з положеннями ліній у досліджуваному спектрі, обчислюють довжини хвиль ліній в останньому. Після цього, користуючись знайденими результатами за таблицями довжин хвиль спектральних ліній, встановлюють той хімічний елемент, якому належить та чи інша лінія досліджуваного спектра. Наприклад, ще в минулому столітті було виявлено, що багато магнітних бур супроводжується полярним сяйвом. У спектрі полярних сяйв виявлено світлі лінії і смуги, які належать атомарному кисню, молекулярному азоту, натрію. Усе це свідчить про те, що молекули і атоми газів верхніх шарів атмосфери під час сяйва перебувають у стані сильного збудження. Викликають таке збудження корпускулярні потоки від Сонця. Електрично заряджені частинки потоку захоплюються магнітним полем Землі. Оскільки магнітні силові лінії сходяться біля магнітних полюсів Землі (які віддалені на $11^{0} 5^{\prime}$ від географічних), захоплені частинки відхиляються до них. Унаслідок цього в полярних областях земної кулі спостерігається полярне сяйво. Так просто і доступно студент коледжу, майбутній учитель початкової школи, зможе пояснити це цікаве явище. 
Уважаємо, що, вивчаючи спектри випромінювання, варто ознайомити студентів і з фізичною моделлю «абсолютно чорного тіла». Відомо, що чим вища температура тіла, тим більше воно випромінює енергії. Зі зміною температури змінюється і кількість енергії, випромінюваної в різних частотах спектра. Однією 3 основних характеристик неперервного спектра $\epsilon$ розподіл енергії в ньому. Відповідно до закону випромінювання (закону Віна) добуток абсолютної температури чорного тіла на числове значення довжини хвилі, на яку припадає максимум випромінюваної енергії, $є$ величина стала - стала Віна:

$$
T \cdot \lambda_{\max }=b
$$

Щоб визначити температуру за законом Віна, необхідно отримати спектр джерела, потім спеціальними вимірюваннями визначити $\lambda_{\max }$ i за згаданою вище формулою обчислити абсолютну температуру. Логічним $є$ те, що зі зміною температури змінюється максимум випромінюваної енергії, що супроводжується зміною кольору джерела світла. Так, у кольорі світного тіла, нагрітого до температури 1000-3000 К, переважають червоні й оранжеві відтінки, із подальшим підвищенням температури воно набуває жовтого кольору (до 5500 К), потім - білого, а при 20000 К блакитного. За цією ознакою оцінюють температуру зip.

Ще одним типом спектра, який особливо часто зустрічається при дослідженні небесних тіл, є спектр поглинання (на фоні яскравої різнокольорової смужки спектра джерела - темні лінії). Усі зорі, за винятком невеликого числа особливо високотемпературних $\left(\mathrm{T} \approx 10^{5} \mathrm{~K}\right)$, дають спектр поглинання. Це свідчить про те, що «поверхня зорі» - фотосфера - випромінює неперервний спектр, а лінії поглинання утворюються у верхніх шарах атмосфери, яка оточує зорю.

Звертаємо увагу студентів на те, що іноді поряд iз лініями поглинання на фоні яскравого суцільного спектра спостерігаються й інші, ще яскравіші лінії, лінії емісії. Спектр Сонця є типовим спектром поглинання $з$ великою кількістю темних ліній - фраунгоферових. Їхнє походження можна пояснити вбиранням та розсіюванням випромінювання атомами та молекулами. Фраунгоферові лінії утворюються у верхніх шарах фотосфери та нижніх шарах хромосфери Сонця. У наш час для вивчення спектра Сонця спектрографи піднімають на штучних супутниках i орбітальних станціях, щоб уникнути поглинання сонячної радіації атмосферою Землі. Дослідження показують, що найбільша інтенсивність припадає на жовто-зелену ділянку спектра. У напрямі коротких хвиль спектр Сонця стає слабким, лінії поглинання зникають, з'являється багато емісійних ліній, спостерігається спад інтенсивності в напрямі довгих хвиль. Отже, за спектром визначають якісний $i$ кількісний хiмічний склад Сония та інших зір.

Цікавим щодо цього є відкриття Гелію. У 1869 р. Лок'єр виявив у спектрі Сонця лінію, що належала елементу, який на той час ще не був відомий на Землі. Вважали, що цей елемент $є$ тільки на Сонці. Цьому елементу дали назву «Гелій» - сонячний. Через 26 років його було відкрито й на Землі [5].

Важливим $\epsilon$ те, що за допомогою спектрального аналізу визначають не тільки хімічний склад зір і газопилових хмар, а й багато інших фізичних характеристик. зокрема температуру, тиск, швидкість руху, індукцію магнітного поля.
Як бачимо, фізика виступає інструментом вивчення небесних тіл. На нашу думку, інтеграція фізики та астрономії, із позицій діалектики, не тільки забезпечує свідоме сприйняття навколишніх явищ як єдиного цілого, а й дає змогу накопичити особистісні якості (відповідальне ставлення до природи, до себе, до оточення, соціальну комунікабельність, інтелігентність тощо) й на цій основі виробити власне ставлення до того, що відбувається в навколишньому світі.

Так формується творча особистість майбутнього учителя початкової школи, його науковий світогляд. Щодо студентів Луцького педагогічного коледжу, то показниками сформованості у них наукового світогляду є наявність знань, поглядів і переконань, які виявляються в різних видах діяльності, здатності до вдосконалення і поповнення знань у подальшому житті. Очевидно, що науковий світогляд, який формується у процесі вивчення фізики і астрономії в коледжі, формує підгрунтя для подальшого здобуття знань.

Висновки. Результати дослідження проблеми інтеграції астрономічних та фізичного знань під час вивчення предмета «Фізика та астрономія» показують, що організація природничо-наукової освіти студентів повинна «розвантажувати» навчальні програми шляхом об'єднання спільних структурних елементів знання в один інтегрований курс, який сприяє створенню цілісної наукової картини світу, формуванню наукового світогляду. Застосування інтеграційного підходу в природничо-науковій освіті студентів педагогічного коледжу сприяє підвищенню інтересу до фізики та астрономії, поліпшенню якості природничо-наукової освіти, дозволяє сформувати цілісне світорозуміння. Інтегроване навчання закладає нові умови діяльності викладачів та студентів, активізує їхню інтелектуальну діяльність.

Перспективи подальших досліджень у даному напрямі вбачаємо у розробці методик системного запровадження інтегрованого навчання, ефективних STEM-занять у практику підготовки майбутнього вчителя нової української школи.

\section{СПИСОК ВИКОРИСТАНОЇ ЛІТЕРАТУРИ}

1. Богдан Т. М. Пропедевтика астрономічних знань учнів у курсі фізики загальноосвітньої школи : автореф. дис. ... канд. пед. наук : 13.00.02 / Національний педагогічний університет імені М. П. Драгоманова. Київ, 2007. 21 с.

2. Державний стандарт базової і повної середньої освіти. Освіта України. 2004 р. 20 січня (№ 5 (500)). C. $8-11$.

3. Філософський енциклопедичний словник / упоряд. В. І. Шинкарук ; Нац. акад. наук України, Ін-т філософії імені Г. С. Сковороди. Вид. 6-те, переробл. і допов. Київ : Абрис, 2002. 742 с.

4. Кирик Л. А. Усі уроки фізики. 11 клас. Академічний рівень : навч.-метод. посіб. Харків : Основа, 2011. 448 c.

1. Нова українська школа. Концептуальні засади реформування середньої школи : від 14 груд. 2016 p. № 988-p. URL: https://mon.gov.ua/storage/app/ media/zagalna\%20serednya/nova-ukrainska-shkolacompressed.pdf (дата звернення: 22.06.2020).

5. Костюк Н. Т. Интеграция современного научного знания: методологический анализ. Київ : Вища школа, 1984. 183 с. 
6. Мартинюк М. Т. Теоретичні засади інтеграції елементів фізичних і астрономічних знань в загальноосвітній школі. Наукові записки. Кіровоград : РВЦ КДПУ ім. В. Винниченка. 2003. Вип. 51. Ч. 1. С. 47-53.

7. Миронов А. В. Подготовка будущего учителя начальных классов к реализации развивающих технологий. Начальная школа. 2009. № 2. С. 89-96.

8. Навчальні програми з фізики й астрономії для 10-11 класів закладів загальної середньої освіти (рівень стандарту та профільний рівень) / упор. О. Ляшенко. Фізика. 2018. № 9 (609). С. 6-37.
9. Носенко Е. Л. Картина світу як інтегруючий і гуманізуючий фактор у змісті освіти. Педагогіка $i$ психологія. 1995. № 1. С. 22-29.

10. Светловская Н. Об интеграции как методическом явлении и ее возможности в начальном обучении. Начальная школа. 1990. № 5. С. 57-60.

11. Засєкіна Т. М., Головко М. В. Фізика: підручник для 10 класу загальноосвітніх навчальних закладів (профільний рівень). Київ : Педагогічна думка, 2010. 304 с.

Дата надходження до редакиї: 21.09.2020 p. 